\title{
From Oskar Parish, Småland, to Manistique, Michigan: Placing People and Depicting Places ${ }^{1}$
}

\author{
By \\ Susanne Nylund Skog
}

\begin{abstract}
Karl Gösta Gilstring's folklore collection is the largest made by a single Nordic researcher in modern times. The basis for the collection was the network of approximately 700 informants with whom Gilstring corresponded. In this article, the empirical focus is on Gilstring's correspondence during the 1960s with one of the informants, Carl Nelson, living in Manistique, Michigan. In the collection, Carl Nelson represents Oskar Parish, despite the fact that Nelson only lived there until he was seventeen and, in his stories, seldom referred to the parish. What were the ideological and scientific premises for such a connection between a person and a place? How did Carl Nelson depict the places of Gilstring's interest? The aim of the article is to explore how Carl Nelson depicted places in his stories, as well as to contextualize the stories with an analysis of the ideological and scientific premises of Karl Gösta Gilstring's collection. In addition, the article aims to highlight and discuss the working method of such an analysis. The article concludes that the reason why Gilstring changed the spatial references of Nelson's letters, making it seem as if they spoke of Oskar Parish probably had to do with the way his collection was organized. The ideological and scientific premises for the collection required that the customs and traditions of an individual, in order to be understood as such, needed a geographical place of origin. However, the analysis shows that the stories included in Carl Nelson's letters do not primarily convey traditions and customs from Oskar Parish. Instead, they depict a mythological landscape recreated by the emigrant Carl Nelson in his American home on the outskirts of Manistique, Michigan.
\end{abstract}

Keywords: Story/stories, Emigrant, Folktale, Place, Folklore collection, Archive, Method.

Nylund Skog, Susanne: "From Oskar Parish, Småland, to Manistique, Michigan: Placing People and Depicting Places", Culture Unbound, Volume 12, issue 1, 2020: 196-216. Published by Linköping University Electronic Press: http://www.cultureunbound.ep.liu.se 


\section{Introduction}

There is probably no other parish in Småland or anywhere else in our country, where folk life is so thoroughly depicted as Oskar Parish in Southern Möre, through the manuscript that is entirely composed of Carl Nelson's collection of letters. (ULMA 34 838) ${ }^{2}$

This quote is taken from Karl Gösta Gilstring's folklore collection at the Department of Dialectology and Folklore Research in Uppsala. ${ }^{3}$ The collection consists of more than 8,000 original letters, as well as many recordings, from which Gilstring made 70,000 records, divided into 117 parish collections and organized according to content. Karl Gösta Gilstring worked with the collection over a period of fifty years, and it is generally regarded as the largest collection made by a single Nordic researcher in modern times (Lindqvist 1993: 63). The basis for Gilstring's collection was the network of approximately 700 informants with whom he corresponded. The abstract above comes from Gilstrings's notes on one of the informants, Carl Nelson, with whom Gilstring corresponded during the 1960s. In this article, the empirical focus has been placed on their correspondence. There is a widespread assumption that a connection exists between a place and the people who inhabit it and that "where someone is born has a special importance for identity"; so this place of birth, for instance, is recorded on birth certificates and in passports (Taylor 2012: 13). In this manner, who people are is indicated by their place of origin and, in turn, they can claim their place of origin as home, a place to which they naturally belong (Taylor 2012: 51).

From the quotation, it is obvious that one person, by himself, could describe and represent a whole parish in Gilstring's collection. What were the ideological and scientific premises for such a connection between a person and a place? Who could represent the places of interest and how was this done?

\section{Aim, Stories and Places}

The aim of the article is to explore how Carl Nelson depicted places in his stories, as well as to contextualize the stories with an analysis of the ideological and scientific premises of Karl Gösta Gilstrings's collection. In addition, the article aims to highlight and discuss the working method of such an analysis.

In the following discussion and analysis, I begin by outlining the theoretical framework of the article, followed by descriptions of Karl Gösta Gilstring, his collection and of one of his informants, Carl Nelson. I then proceed to a description of how I have worked with the collection. Thereafter follows the analysis of how places are depicted in stories by Carl Nelson. 
In the article, stories are defined as performances, meaning that stories in both written and oral form are action that is framed, presented and highlighted (Ryan 2004: 8, Schechner 2013: 28). The analysis addresses questions of how and when a story is performed and for what purposes.

There are many reasons for concentrating the analysis on stories: Primarily, stories are considered containers of condensed meaning, offering themselves as flexible communicative tools that are useable in different ways for different purposes. Through the use of stories, tellers can present themselves, argue with or against issues that are important to them, and construct themselves as heroes, victims, sufferers etc. This perspective on stories presupposes a connection between form, content and meaning. The style, structure and form of a story are considered resources for knowledge about social and cultural conditions (Nylund Skog 2012). In addition, they function as signals that give meaning to content for the listener or the reader (Arvidsson 1999: 196). This means that there is always a tension between what the teller can achieve by telling a story and what is required of a teller in order to be believed.

Secondly, since stories are different from other forms of communication, they offer the researcher gateways to processes where meaning is created and maintained. Thirdly, many genres of stories have long histories and traditions, which means that the researcher can gain access to how meaning making is placed in layers of histories. In conclusion and simply put, stories are always told or written for a reason and it is the researcher's task to explore these reasons and how they are embedded in, and part of, processes of communication.

Despite their physical existence, places are also socially and culturally constructed, and emotionally connected to the people inhabiting them, or telling about them. Places offer guidance and steadiness, make us remember and recognize ourselves and tell us who we are by showing us where we are (Povrzanović Frykman 2001: 128, Heimo 2006: 50). Place is therefore understood not only as a "thing in the world", but also as an important way of understanding the world (Cresswell 2015: 10). In this article, the analysis focuses on how the geographical places are depicted and transformed in stories and become new (or at least different) places. With inspiration from discussions on how the local is connected to the global and how space is transformed into place, places are regarded as made by histories of movement and travel, connected and created by stories (Massey 2007 and 2010). In other words, places are made meaningful by stories, and consequently, the same geographic place represents a variety of histories and layers of meaning (Farahani 2007: 38, compare Hall 2002: 242). 


\section{The Collector and his Little Congregation}

Karl Gösta Gilstring is described as a warm-hearted priest, an enthusiastic teacher and a devoted collector of folklore. He was born in 1915 in Östergötland, took his high school diploma in Linköping in 1934 and was ordained in 1941. By the time of his retirement in 1980, he had spent a total of twenty-two years as a priest and more than a decade as a high school teacher. During all these years, he spent his free time working on the folklore collection and he continued this work until his death at his desk in 1986. Karl Gösta Gilstring was married and had one daughter and two sons (ULMA 34 838). Gilstring was awarded an honorary doctorate at Uppsala University in 1975 and in 1985 he received a prize from the Royal Gustavus Adolphus Academy for Swedish Folk Culture, for his "remarkable collection of Swedish folklore collected during more than fifty years of work". The same year he was awarded a scholarship as "our country's most diligent folklore collector" (ULMA 34 838).

It is no coincidence that Gilstring's collection was donated to the Department of Dialectology and Folklore Research in Uppsala (DFU), the former Institute of Dialect and Folklore Research in Uppsala (ULMA). Gilstring's cooperation with ULMA started in the 1940s when he was working with Professor Åke Campbell on the Atlas of Swedish Folk Culture (1957). Gilstring also studied folklore in the 1950s under Dag Strömbäck, the former director of ULMA and Professor of Nordic and Comparative Folklore Research, and he wrote his licentiate thesis at the Department of Religion and History, tutored by Professor Carl-Martin Edsman (ULMA 37 313).

In a letter dated 1 December 1970, Gilstring wrote to his former tutor Edsman about how he came to start his collection of folklore: "I was in high school and had been at home in Hof for my grandmother's funeral. She carried the past of Östergötland, as few did, born in 1851 in Biskopsberga, Allhelgona Parish, close to Skeninge. From that moment I decided to collect what I heard" (1 December 1970, ULMA 34 838). Gilstring knew that the time was a "few minutes before twelve" and that the last of the people who held the oral tradition soon would be dead, as the local newspaper Vimmerby tidning wrote (17 November 1984). Gilstring's aim was to collect and save everything that could be saved, before it was too late.

Gilstring's focus of interest required large amounts of material and his aim was to document all aspects of folk life and tradition (Lilja 1991: 91, Lindqvist 1993: 74, ULMA 37 313). He regarded himself as an explorer, doing necessary pioneer work in parishes that until that time had been blank spots on the map of folklore (Lindqvist 1993: 72). Articles about Gilstring accentuate his historical knowledge and interest in the past (ULMA 34 838). Comments on his lack of interest in everything new or modern are also to be found, as well as criticism of 
his outmoded research methods (ULMA 37 313). To begin with, Gilstring shared his interest in heritage, diffusion and the fear of losing traditions of the past with many, but by the 1960s, the discipline of ethnology shifted interest towards the present time and cultural processes, and many researchers abandoned working with folklore collections such as the one made by Gilstring (Dundes 1986, Lilja 1991: 90, Lindqvist 1993: 65-66).

The basis for Gilstring's collection was in the network of approximately 700 informants with whom he worked over the years. He wrote about ten letters every day to these people, who were spread all over Sweden, Åland, Finland, and Swedish North America. Gilstring required that the people he engaged with should be born before 1920. He got hold of them via appeals in papers such as Kvällsstunden and Svenska Amerikanaren Tribunen (Lindqvist 1993: 70-71). ${ }^{4}$ Gilstring called his informants his "little congregation" and was very involved in their lives (ULMA 37313 ). In a letter to his "dear friends", he thanks them for all they have done for him and for the science of folklore (26 August 1958, ULMA 34 838), and in a letter to his family as early as 1953, he writes that the informants are his friends. They have stood by him and have given him the human community that has meant "the most" to him (4 September 1953, ULMA 34 838).

\section{The Collection of Answers to 3,000 Questions}

In order to understand and work with Karl Gösta Gilstring's collection, it must be placed within the ideological and scientific framework of the time. This framework had taken form by the end of the nineteenth century and was being practically implemented during the first decades of the twentieth century. This was the epoch of inventory and mapping, and the explorer of the old folk life and tradition joined the group of scholarly representatives who made inventories and collected large amounts of material, categorizing them through methods for achieving scientific knowledge (Gustavsson 2014: 41). Theories from the natural sciences were transformed into methods for the science of folklore, which in many respects was a young science striving to be regarded as serious. It was a question of collecting evidence, of rewriting, categorizing and placing data on maps (Löfgren 1995: 141, see also Ekström in this issue).

Karl Gösta Gilstring had a battery of 3,000 questions that fell into approximately twenty categories, based on various topics, which were also the basis for the chapters in his parish collections (Lindqvist 1993: 66). The material was also divided into different headings, such as the year, life, work and rest, sickness and health, sayings and proverbs, and play and pleasure (ULMA 34 838). Although Gilstring's questionnaires are characterized by his own personal and informal style, the questions are detailed and have much in common with questions from the archives to which he contributed (Lindqvist 1993: 67-68). This 
is the case both in the more generalized questionnaires that were published in the weekly press mentioned previously, and in the questionnaires that he sent to his informants. Gilstring also sent out circular letters with questions. On November 8 1960, for example, he wrote to his "friends" in the USA and Canada, wondering how they "had it with water-wheels and other memories". He added that he was grateful for the opportunity to return once more with questions (ULMA 34 838).

In his role as researcher, Karl Gösta Gilstring assessed the letters he received and transcribed the parts that he found interesting. In this work, he was primarily guided by the methods used by ULMA and other folklore archives during the first decades of the twentieth century. As previously mentioned, Gilstring contributed to the Atlas of Swedish Folk Culture, a project in which traditions and customs were placed on maps. The working methods of this project had high scientific value in the 1930s and 1940s; the purpose was to show the diffusion of geographical similarities and differences across the country (Skott 2008, Lilja 2012: 13). In a speech in 1938, the head of the board of the archive, Professor J.A. Lundell, captured the basic ideas of these methods. The speech was given in honour of the director of ULMA, Professor Herman Geijer, on his retirement.

Then the information must be scrutinized and its content checked. Gaps should be filled through new questions. Then this material, in order to become accessible to science, must be registered in detail, to a large extent rewritten on slips of paper, which thereafter fills boxes and cupboards. This needs to be done soon: new forms of old culture are breaking in and creating confusion, only the oldest are still faithful bearers of older local forms of language and inherited wisdom. When these old men and women pass the border into the unknown land, we will have no answers to our questions (Lundell 1939: 7). ${ }^{5}$

In accordance with these methods, Gilstring rewrote parts of the letters that he considered valuable and made excerpts for each category of content. It required special skills to determine what should be kept and collected. Among other things, it was a matter of distinguishing between popular and learned, oral and written, genuine and spurious, as well as primary and secondary. What was left were the ideal and typical descriptions in the form of clear-cut categories that were easy to characterize and distinguish (Lilja 1999). When this work was done, Gilstring put the excerpts into binders according to geography and content. In that manner, he created a series of secondary sources. 


\section{With Roots in the Stony Soil of Småland}

Carl (Charles) Nelson was born 1878 in Western Lillaverke, Oskar Parish, as Karl Oskar Nilsson. He emigrated to the United States of America in 1896, joining the more than one million other Swedes that left the country for the USA between 1830 and 1930. Carl Nelson made only one short return visit to Sweden in 1900, and thereafter spent the rest of his life in the USA. In 1918, he married his cousin Hilma, with whom he lived in Manistique, Michigan, until his death in 1969. In Gilstring's collection, Carl Nelson has number 92:1 and there are 2166 excerpts in his name made by Gilstring (ULMA 34 838: 92: 1).

The correspondence between Gilstring and Nelson began in 1960, when Gilstring had an advertisement to which Nelson responded. The correspondence between them was intensive, especially during the years 1962 and 1966, with about 40 letters from Nelson each of these years (DFU 40 265: 282). In the archive, there are 285 letters from Nelson to Gilstring, and even though not all the letters from Gilstring to Nelson have been kept, there are 318 of them left in the collection (DFU 40 265: 284).

Carl Nelson became an important informant to Gilstring, not only because he was a diligent writer or because of his literacy, and "knowledge of humans and old Swedish traditions", but mainly because his roots went deep in the stony soil of Småland (DFU 40 265: 284). Gilstring repeatedly mentions that Nelson, after he emigrated, returned to Sweden only once and therefore, he argues, Nelson's memories belong to the nineteenth century and reflect life as it was lived during those days. In his description of Nelson, Gilstring carefully describes what he calls the Big Agebo Family, from which Carl Nelson and his wife Hilma originated. They both came from the same "root of a widely branching family tree". Gilstring writes that in this family "son after father have ploughed the soil as long as we can follow the family's destiny" (Svenska Amerikanaren Tribunen, 4 July 1973).

In addition to the deep roots in the stony soil of Småland, Carl Nelson grew up with three mothers, namely his mother, his grandmother and his great-grandmother. The later, called Old Ingrid, was born in 1800. According to Gilstring, in her childhood she had been able to meet people that in their turn met people born in the seventeenth century. Old Ingrid lived until 1892 and Gilstring writes that Nelson remembered a lot from her (DFU 40265: 284, ULMA 34 838).

On several occasions, Karl Gösta Gilstring certifies that Carl Nelson gives a true and genuine picture of Oskar Parish in the nineteenth century and earlier. Gilstring also asked Nelson whether his visit to Sweden in 1900 had affected his memories from before the emigration, and if his social life with Swedes in Manistique had changed his views of his childhood in Sweden. The answer from Nelson is NO, Gilstring writes, and argues that the collection from Nelson testifies to how ductile the memory is, since it can "keep safe and intact the impressions from childhood and early youth" (DFU 40 265: 284, ULMA 34 838: 92: 1). 
In a letter to Gilstring dated June 8 1967, Nelson describes how his memory works.

You ask me how I can remember things from my childhood. In short, I can say that I have a good head for remembering. Yes, but what is a good head for remembering? For me there seems to be a phonographic record that has registered every occasion in my life. There is also colour television on that record. So when I am asked about something that has happened, a certain time or place and how something happened [...] I see and hear what happened then and there. It might sound a bit funny, but that is how it seems to be. The human brain is a marvellous archive that can hide all those events that have taken place in a human's life and we can enter and call up whichever record of our lives we want to study. The human does not come from the monkey (DFU 40 265: 282: 255). ${ }^{6}$

Here it becomes clear that from Nelson's point of view, it is not entirely about his roots in the soil of Småland, but also about his unique "head for remembering". Nelson was deeply religious and belonged to the congregation of Jehovah's Witnesses. From this quotation, we can see that he was sceptical of evolutionary ideas that claimed that humans originated from monkeys. In other letters, he protested against female clergymen and priests, defended legalized prostitution and worried about the dangers of modernity.

As mentioned earlier, Gilstring was not the only one holding on to the thoughts of the time which argued that modernity was destroying and changing original traditions and customs. From this quotation, it seems that Nelson too, albeit in his own way, agreed with Gilstring about the danger of heritage disappearing. In other words, Nelson fulfilled all the criteria of an excellent informant of the time. His deep roots in the stony soil of Småland, the undestroyed and unaffected memories and the direct connection to a specific place gave his statements authenticity and legitimacy. The three mothers added extra historical depth that Gilstring found valuable and motivated him to thoroughly investigate Nelson's family relations and place them geographically within Oskar Parish.

\section{Getting to know the Men and the Collection}

From this first part of the article, many aspects of my working methods have become visible; for example, I have counted the letters of each writer and organized them chronologically. Before that, I spent several years working with similar material and a few years getting familiarized with Karl Gösta Gilstring's collection. As previously mentioned, the collection is large, and initially it gave the impression of being well organized with the properly labelled blue binders and tables of contents. 
However, this orderly system only concerned the final excerpts that Gilstring made from letters and recordings. The unfinished excerpts and manuscripts, the many drafts of different parish collections, of portraits of informants and of articles and questionnaires for newspapers, were - together with the thousands of letters - left in poorly marked boxes, binders and envelopes. To get an idea of the character of this material and of Karl Gösta Gilstring's working methods, I have spent several weeks of "fieldwork" in the archive. In combination with reading literature about the formation of the archive and of theories and methods during Gilstring's active period, I have gained some rudimentary knowledge of his collection. As I argue above, I regard such knowledge as necessary when analysing the letters.

When choosing which of the many informants to concentrate the analysis on, it has been a question of both method and coincidence. In my experience, it is an analytical advantage to have an empirical body of material that is rich and clearly defined by theme, form or, as in this case, person. Therefore, I searched for an active informant in Gilstring's collection, preferably including (1) letters both to and from Gilstring, (2) letters as well as recordings from the same informant, (3) where Gilstring had made many excerpts and (4) during a period of ten years in the 1960s, when Gilstring seems to have been most active. In Carl Nelson, I found such a person. In addition to being an active informant, there are letters from both him and Gilstring in the collection. Nelson was also interviewed in 1967 by Barbro Klein (Sklute at the time), who supervised my doctoral thesis and who happened to donate the recordings with Nelson as research material to the archive some time prior to her death in 2018 (bd 11 420-22). To make the choice even easier, a sound technician digitized the old recordings. With these and the typewritten letters, there was no argument against concentrating on Carl Nelson.

When the decision was made, I started out by searching the archive to make sure I did not miss other files on Carl Nelson. I wanted to ensure that I knew of all the available material concerning Nelson. There was nothing except the letters and the recording. The letters were in three different boxes, presumably mirroring where in the working process Gilstring had been when he died in 1986. Thereafter, I organized the letters chronologically in order to gain insight into how their correspondence was established and changed over the years. I also read a couple of letters from each year and tried to match some of Gilstring's questions with some of Nelson's letters with answers. This was not as easy as one might think; on the one hand, Gilstring himself had two overlapping systems of numbering the letters and often repeated questions. Nelson, on the other hand, did not answer directly. He could either spread his answers over several letters or answer questions from several of Gilstring's letters in just one of his.

After some time, when I had an idea of the character of their correspondence, I searched Nelson's letters for stories of any kind. I would like to point out that I use the term story in a very broad sense, including all oral and written forms of storytelling used in communication, for example, personal experience narratives, 
reports, jokes, anecdotes and legends. For the teller, they serve as flexible tools useable in different ways for different purposes (Bauman 1992: 58). This means that a story framed as a folk tale is used and understood differently than one framed as a legend or a personal experience narrative.

I found that Nelson had an extensive repertoire, dominated by some themes and stories. I have concentrated the analysis on such stories, and in the following discussion, I will show how the stories are thematically and geographically linked, as well as organized by meaning and message.

\title{
Tales of Caves and Mountains
}

In a letter to Karl Gösta Gilstring, dated May 31 1967, Carl Nelson writes about a cave in Kroksmåla. Gilstring has probably asked him a question that he tries to answer because the letter begins with the words "Thank you for your letter of 25 May. You speak of caves" (DFU 40 265: 282: 254).

\begin{abstract}
There was a lot of talk about a cave "underground passage". It was in Kroksmåla. The opening was on the border of Krokstorp and Lillaverke, by the southern end of the Krokstorp Lake. The saga tells that there were 7 farmers that tied together 7 ox reins to a line and went into the cave as far as the line allowed. They did not dare to go further. They also said that a dog had gone into the cave but it never came out. They heard it barking far away in the cave. There was a lot of talk about that cave in Lillaverke when I was there, but nobody dared to go in there. That is the only cave I have heard about in that neighbourhood (DFU 40 265: 282: 254) ${ }^{\text {? }}$
\end{abstract}

According to Carl, this is a saga (folk or fairy tale) about seven farmers that tied together seven ox reins. None of them dared to let go of the reins and venture further into the cave. Carl does not say why they wanted to enter the cave. Maybe there was a treasure inside or perhaps they wanted to fetch the dog that was in there. The introductory part of the story has much in common with a type of folk legend ( $\mathrm{T}$ 100) where the events take place in a subterranean passage between a monastery and another building (af Klintberg 2010: 354). In Carl Nelson's story, the place-the underground passage or cave-forms the starting point for the tale of the seven farmers. Nelson writes that it is the only cave that he has heard about in that neighbourhood, meaning Oskar Parish.

Carl Nelson's birthplace, Western Lillaverke, is situated in Oskar Parish in Kalmar County, a region with forests and small lakes that is criss-crossed by the Hagby river vein. The name Lillaverke comes from the word verke, which is a catching device for fish. Perhaps the name has its origin in one such device in the Hagby river vein (Nybrokunskap). That Lillaverke is located in an area with 
many forests and lakes is often evident in Nelson's stories. This saga takes place in Kroksmåla, which is situated one and a half kilometres from Western Lillaverke, close enough so that what happened there is talked about in Western Lillaverke.

I have not found any more stories of the cave in Kroksmåla in the letters (or recordings). Stories of the Stacka Mountain, on the other hand, are numerous. The mountain is situated in Svalehult, Madesjö Parish instead of Oskar Parish. This is what Carl Nelson writes in one of the first letters to Karl Gösta Gilstring on 14 March 1960:

This is the saga of Stacka Mountain. There was a Boatswain named Svala. His home was in Svalehult, Madesjö Parish. He was on a long journey in the service of the crown. The ship was in the Pacific Ocean when one day it stopped, and a giant looked over the rail and asked for Boatswain Svala. Svala was brought to the giant (Svala was alarmed). The giant said to Svala "Do not be afraid. Nothing bad is going to happen to you. You know where Stacka Mountain is. I could not stay there and hear the church bells, so I went away, but forgot my dog in the mountain. When you come home, go to the mountain and set my dog loose. He is tied up there in the mountain. Do not be afraid, since as soon as the dog is lose he will run to me. Then you will get all that is in the mountain. There are three barrels of gold and a table that has a golden top and a silver foot. The dog is tied with a golden chain." When Svala came home, he went to the mountain, found the key and went in. However, when he saw the dog, he became so frightened that he ran out and closed the door and threw away the key. Once he got home, he told about what he had seen and the word was spread that there was gold in Stacka Mountain. People came and started digging to find the gold but instead of gold, they got sick. So, it was forbidden to dig there. After some time Svala lost his mind. Stacka Mountain is in Svalehult, Madesjö Parish. (DFU 40 265: 282: 3$) 8$

Carl Nelson classifies this story too as a saga, even though it has the characteristics of a legend. In contrast to a saga, which takes place in a distant and unrealistic place where magical things happen, Nelson's story is set in historical time and the geographical place where the event occurred is mentioned both at the beginning and at the end of the story (af Klintberg 2010: 13). In this case, there are many similarities between Nelson's story and a folk legend type (J36E) where a giant asks a sailor to release a dog that is left in the mountain where the giant used to live (af Klintberg 2010: 162). However, the ending of Carl Nelson's story differs from the legend type where the sailor succeeds in letting the dog free and is rewarded with the giant's treasure. 
By framing the story as a saga, Carl Nelson assures the reader that he does not believe the story to be true. However, he both begins and ends the story by mentioning the name of the place. In that manner, he creates authenticity not by telling about something that he believes actually happened, but by placing the story in a physical landscape. And indeed, Svalehult exists, as does the parish and the church called Madesjö. There is also a long line of seamen from Svalehult who have taken the name Svala. In that way, they have carried the name and the place Svalehult with them around the world.

Here it is obvious that places do not only remind us about events in the past. In stories, they also become evidence for the authenticity of what is told and give authority to the teller (Johnstone 1990: 126-135, Heimo 2006: 50). The mention of Svalehult also transforms the landscape of Carl's childhood into a magical place of tales and wonder. However, even if Carl Nelson did not believe that there was a giant living in the cave, he believed other aspects of the story to be true. The first time he told the story to Barbro Klein, he concluded it by remarking that the boatswain became insane and that that was true since Nelson's father knew the boatswain (bd 11 420).

In her thesis on legends and folk belief in New Sweden, Barbro Klein remarks that the informants often raised the issue of belief and this sometimes resulted in animated conversations between informants (Klein 1980: 20). This is exemplified by Nelson's remark that his father knew the boatswain. The topic is also raised in connection with yet another version of the story about Svala told by Carl Nelson and his brother during the interview. Barbro Klein then asks the brothers who told them the story. Carl Nelson's brother claims to have heard it from their father, but Carl Nelson objects and argues that it was told and believed by almost everyone in the old days. Yet, he also concludes this version of the story by referring to the place: "It was not far from Lillaverke. It was by Svalehult. And Svalehult bordered on Lillaverke" (bd 11 421).

The giant of the tale has fled from Stacka Mountain since he could not stand hearing the church bells ring. This is a common motif in stories about giants and their relatives, the trolls (af Klintberg 1977: 26). In one perspective, the tale about Stacka Mountain captures Christianity's victory over old superstition, a theme to which Carl often returned. It is interesting, though, that this legend type (J63E) is placed under the heading Resistance against Christianity, but when Carl Nelson uses the type, he transforms the message into the opposite. In an orally performed version, Carl introduces the tale of Stacka Mountain with the words: "The story was. It was during the time when Christianity came to Småland" (bd 11 420).

It has been claimed that it is easier to recall and depict a journey with the help of places rather than with dates and time. In such a perspective, memory is spatially and not temporally organized (Heimo 2006: 53). One reason for this 
could be that time has passed while places still exist, even if only in memory, as is the case with Nelson. He has not visited the places he talks about in over sixty years. He also performs the story in a place far away (Kaivola-Bregenhøj 2006: 34). From this perspective, the places and events are more important than time, which in this case Nelson loosely defines as the time when Christianity came to Småland (Johnstone 1990: 130-131; Heimo 2006: 52; Nylund Skog 2012: 55).

It has been noted by many folklorists that exact markers of place are narratively important, especially when it comes to legends (af Klintberg 1977: 12). Barbro Klein writes that by thoroughly describing where something extraordinary took place, the teller attempts to convince the audience that the supernatural events they talk about actually happened in a world that the teller and perhaps the audience are familiar with (Klein 1993: 96). In that respect, the stories do not primarily concern the physical places mentioned or, in the case of Carl Nelson, even his childhood landscape. Carl Nelson says that all he remembers from his childhood and youth in Sweden is poverty and hard work (DFU 40265: 282: 11). Consequently, in his stories, the geographical places in Oskar Parish are transformed into mythological places without geography and, as Klein writes, the outer topography becomes a depiction of an inner condition (Klein 1993: 96). In Carl Nelson's stories, this condition is portrayed as a mythological landscape marked by a romantic longing for a lost and pristine time. In that vein, the places he describes are only present in his stories.

\section{Stories Without Place or Time}

Another aspect that connects to the religious theme of the saga of Stacka Mountain is that a person who yields to temptations gets into trouble. In the tale, those who search for the giant's treasure become insane and Svala loses his mind (bd 11420 ). The giant appears to be reasonably nice. He repeatedly assures Svala that he does not have anything to fear and that he will be richly awarded if he helps the giant. With the story, it is as if Carl Nelson urges the listener and reader not to be fooled by promises of gold and treasure. According to the story, such promises lead away from God to sickness, insanity and misery. The presence of the dog in this story, as well as in the one about the cave in Kroksmåla, strengthens this interpretation; in many folk legends, the devil appears in the shape of a dog (af Klintberg 2010:214). If we interpret the dog in the saga of Stacka Mountain as the devil, to succeed in letting the dog loose is equal to letting the devil loose.

The thematic (and religious) connection between the devil and temptation is also present in another story told by Carl Nelson on two occasions during the interview with Barbro Klein and written twice in letters to Karl Gösta Gilstring. Briefly, the story is about a poor bookkeeper that falls in love with a rich girl 
and willingly sells his soul to the devil in order to win the young girl's heart and marry her. ${ }^{9}$ The bookkeeper signs a contract with the devil who promises him twenty years of happiness with the girl. They sign the contract with blood and the bookkeeper puts it in a drawer. The devil keeps his part of the deal and soon the bookkeeper learns that he has inherited a fortune from a distant relative and can marry the girl. They live happily and by the end of the twenty years, the bookkeeper looks for the contract but cannot find it. He becomes ill and dies. After his death, the contract is found behind the drawer, but whether the devil actually took the bookkeeper's soul is "never told" (DFU 40 265: 282: 280).

This story also seems inspired by a well-known folk legend (L32) where a contract signed with the devil is placed in a keyhole of a church (af Klintberg 2010: 220-221). On the other hand, the most central aspects of Carl Nelson's story are not part of this legend type. One such aspect that is clearly depicted and recurrent in all versions concerns the signing of the contract. In the first version from 14 March 1960, Carl writes that "Satan tore a small hole" in the hand of the bookkeeper so he could sign the contract "in his own blood" (DFU 40 265: 282: 3). In the second written version from 30 June 1969, Carl writes that Satan took the hand of the bookkeeper, tore a hole and said: "Here you have ink! Now write!" (DFU 40 265: 282: 280). During the interview, Carl Nelson says that the devil and the man "made a contract and there was a scar here in the hand so the blood ran" (bd 11 420). In every version, Carl Nelson also emphasizes that the man and the girl were happy, that the man put the contract in the drawer and that it was found after his death. However, it is only in one version of the story that the poor man is a bookkeeper, namely, the version that Carl Nelson wrote in 1969 in response to a question from Gilstring about the devil. Although the story seems inspired by one or more folk legends, the theme of man selling his soul to the devil is also a folk tale motif (M211 in Thompson 1957: 39). In that manner, Nelson's version of the story appears to be a mix of several folk genres, where the tearing of a hole to get access to the bookkeeper's blood is central.

The reason why Carl repeated this story, and in the way he did it, is probably because it concerned issues valuable to him. With stories, we can express topics and viewpoints that are important to us without saying so explicitly (Nylund Skog 2005). I think this is the case with the story of the bookkeeper who sold his soul to the devil. The story delivers several intertwined messages of importance to Carl Nelson. It is obvious that the story discourages people from signing a contract with the devil, a message that is to be symbolically understood. The story deals with religious issues and warns the listener not to be fooled or lured by promises of riches and happiness, since it all comes at cost. The moral of the story could also be that poor and rich people should not marry or that a person should not marry under false premises. The man was poor and perhaps Carl Nelson argued that the 
girl should have accepted him without the inherited fortune. Another message is to humbly bow before God and accept what life offers. Perhaps Carl Nelson conveyed with the story that twenty years of happy marriage always comes at a price. No matter what the message of the story is, it offered him an opportunity to perform an entertaining piece of important information.

I find it interesting that this story in the style of a folk tale is not located in a place. Nor are the characters or the surroundings described in any detail (Gustavsson \& Palmenfelt 2018: 15). The story does not convey when and where the contract is signed. In one version Carl Nelson says that the man inherits money from an uncle in Brazil (DFU 40265: 282: 280), but that is all we get to know about the places of the story. During the interview, Barbro Klein repeatedly asks Carl Nelson questions about who told the stories and where they were told. Concerning the story about the man who signed a contract with the devil, Nelson answers that it is "the same again, as with all other stories". They do not have "place or time" (bd 11 420). Perhaps this lack of time and place makes the story especially interesting and repeatable. As with folk tales, it does not matter for the moral of the story whether it is about people in America or in Oskar's Parish in the eighteenth, nineteenth or twentieth century. In that respect, the story has much in common with a folk tale and is portable in character. It offers Carl Nelson an opportunity to entertain while recreating the magic landscape of his youth and simultaneously expressing moral standpoints.

Earlier, I mentioned that Gilstring rewrote parts of the letters that he found valuable and made excerpts for each category of content. In that manner, Gilstring has rewritten the story of the bookkeeper who signed a contract with the devil from Carl Nelson's letter, word for word (DFU 40 265: 282: 280). However, he apparently had trouble categorizing its content in relation to his system and left it without a heading. Maybe it was Carl Nelson's remark that there were many stories of people who sold their souls to the devil that convinced Gilstring to make the effort of rewriting the story, even though stories like this did not automatically fit into his system of categories. It is obvious from his collection that it was much easier for him to categorize short remarks and direct answers to questions (ULMA 34 838).

The first version of the story about the man who sold his soul to the devil was written by Carl Nelson directly after the tale about Stacka Mountain (DFU 40 265: 282: 3). As we recall, one theme of that story was that those who were tempted by promises of gold and searched for the treasures in Stacka Mountain became sick. In the story about the bookkeeper who sold his soul to the devil, it leads to death, although after twenty years of being happily married. The stories are also connected by the theme of the devil since he was often pictured as a black dog (af Klintberg 1977: 35). Perhaps it was the devil who was captured in the cave at Kroksmåla and trapped in Stacka Mountain. In that vein, it is not only places that connect times and stories, certain topics and themes can do the same job. Among 
others, the folklorist Katharine Galloway Young has demonstrated how stories are thematically connected and constructed in such a way that they serve as context to one another, as well as explaining and highlighting the moral messages (Young 1986, Nylund Skog 2005: 165).

\section{Concluding Remarks}

By way of introduction, I wrote that we imagine that there is a connection between a place and those living there. In Karl Gösta Gilstring's collection, this supposition forms the theoretical foundation. The collection presupposes that a person's place of birth gives that person her or his identity, as well as offering a home, a heritage and belonging (Ahmed 1999, Taylor 2012: 51).

In Gilstring's collection, Carl Nelson represents Oskar Parish even though Nelson only lived there until he was seventeen and seldom referred to the whole parish in his stories, but rather to the village of Western Lillaverke and other parishes. This fact seems to further motivate Gilstring to investigate Nelson's family relations, to include Nelson's wife in this investigation and to connect them both to what he called the Big Agebo family, which was spread all over the parish.

The reason why Gilstring changed the spatial references of Nelson's lettersmaking it seem as if they spoke of Oskar Parish rather than Western Lillaverkeprobably had to do with the way his collection was organized. Whether or not a parish was complete depended on whether Gilstring had answers to all of his 3,000 questions. When he had collected enough excerpts and organized them in relation to this framework, he considered the parish collection finished. In that manner, some parish collections contain contributions from many persons, while others, such as the one from Oskar Parish, are made of letters from only one person.

To summarize, when contributing to the collection, Nelson, like all the other 700 in Gilstring's small congregation, came to represent a place in Sweden. Thereby, he and the others also came to represent traditions and customs in a specific geographical area. The ideological and scientific premises for the collection demanded that a person's customs and traditions, in order to be understood as such, needed a geographical place of origin.

Initially, I wrote that Gilstring argued that he did not think that there was a parish in Småland or in the country as a whole, whose traditions were as thoroughly depicted as Oskar Parish thanks to the manuscript made from Carl Nelson's letters (ULMA 34 838: 92). The many excerpts that Gilstring made from the correspondence with Carl Nelson are of course an important source of 
information of how Carl Nelson remembers customs and traditions and retells stories from his life as a child in Småland at the end of the nineteenth century. However, as the analysis in this article shows, the stories in Carl Nelson's letters do not primarily convey traditions and customs of Gilstring's interest. Instead, they depict a mythological landscape recreated by the emigrant Carl Nelson in his home on the outskirts of Manistique, Michigan.

In this article, I have demonstrated that the correspondence between Carl Nelson and Karl Gösta Gilstring can be analysed in order to gain knowledge of how stories serve to accentuate and highlight issues that are important to the teller, as well as of how places are depicted and made meaningful. However, the correspondence is also suitable for analysis of childhood life stories in Sweden at the end of the nineteenth century and of how a folk life researcher such as Gilstring constructed knowledge of traditions and customs of past times. In addition, the letters from Nelson are resources for knowledge on life in America during the 1960s and earlier. In them, he describes his work on the railways, the passages to America from Sweden, his journeys in the new country, as well as his time in Nome, Alaska, in search of gold. Gilstring's letters, on the other hand, describe his family life, his clerical duties as well as his work as a high school teacher. In the letters, he mentions colleagues, relatives and friends. He describes sickness, happiness and struggle. In that manner, the reader learns about the conditions and life of an educated middle-class man in Sweden. In conclusion, for someone interested in cultural processes and life in the first part of the twentieth century, the correspondence between the Swedish American Carl Nelson and the folk life researcher Karl Gösta Gilstring offers an abundant empirical resource.

Susanne Nylund Skog is a researcher at the Institute for Language and Folklore, the Department of Dialectology and Folklore Research in Uppsala, Sweden. She is docent (associate professor) of ethnology at Uppsala University, Sweden, and of Nordic folklore studies at Åbo Akademi University, Finland. She defended her doctoral dissertation in ethnology on childbirth stories at the University of Stockholm in 2002. She has also done extensive ethnographic research on Jewish life in Sweden and on stories told by birdwatchers. With performance and narrativity in focus, she has explored issues such as anti-Semitism, whiteness, intertextuality, masculinity, emotions and materiality. She is currently doing research on archive collections within the project TillTal-Making Spoken Cultural Heritage Accessible for Research funded by Riksbankens Jubileumsfond, the Swedish Foundation for Humanities and Social Sciences from 2017 to 2020 (SAF16-0917:1). Email: susanne.nylund.skog@sprakochfolkminnen.se 


\section{Notes}

1 This article is part of the multidisciplinary and methodological project Tilltal (Tillgängligt kulturarv för forskning $\mathrm{i}$ tal, 'Accessible cultural heritage for speech research'), financed by the Royal Swedish Academy of Letters, History and Antiquities and the Swedish Foundation for Humanities and Social Sciences (Riksbankens Jubileumsfond) from 2017 to 2020 (SAF16-0917:1).

2 Det torde icke finnas någon enskild socken i Småland eller huvud taget i vårt land vars folkliv är så genomgående skildrat som just Oskars socken i Södra Möre genom det manuskript som är helt sammanfogat av Carl Nelsons brevsamling. (ULMA 34 838: 92).

3 In 1914 a research institute for the documentation of dialects and popular tradition was set up in Uppsala, followed by the foundation of a special Folklore Department within the Institute in 1928. Today, the Department of Dialectology and Folklore Research in Uppsala is part of the Institute for Language and Folklore, a Swedish government agency with a focus on dialects, language policy, language planning, names and folklore. The archives of the Institute houses one of Sweden's largest folklore collections. Karl Gösta Gilstring's folklore collection was donated to the archive in Uppsala in connection with his death in 1986.

4 Svenska Amerikanaren Tribunen was a merger of several American paper in Swedish to a weekly paper, published in Chicago from 1936 to 1966. Kvällsstunden is a Swedish independent weekly paper published in Västerås since 1938, where stories describing Sweden in the past are still frequent.

5 Translated from Swedish: Men så måste de upplysningar som inkommer granskas och till sin innebörd kontrolleras. Luckor utfyllas genom nya frågor. Så måste detta material, för att bli för vetenskapen tillgängligt i detalj registreras, till stor del skrivas om på lappar, som sedan fyller lådor och skåp. Detta måste göras snart: nya kulturformer bryter in och vållar stor förvirring, endast åldringar är ännu trogna bärare av äldre lokala språkformer och fäderneärvd visdom. När dessa gamla män och kvinnor gått över gränsen till det okända landet, får vi inga svar på våra frågor (Lundell 1939: 7). 6 Translated from Swedish: Du frågar hur jag kan komma ihåg saker och ting från min barndomstid. I korthet kan man säga det är just ett godt kom ihåg. Ja, men vad gör ett godt kom ihåg? För mig tyckes det vara en phonograf skiva som spelats in varje händelse i mitt liv. Det är också färg TV på den skivan. Så när jag bliver tillfrågad om något som hänt, en viss tid eller plats och hur något hände /.../ (sinne) ser jag, och hör vad som då hände och det hände. Det kanske låter lite lustigt, men så tycks det vara. Människans hjärna är ett förunderligt Arkiv som kan gömma alla de händelser som har hänt i en människas liv och vi kan gå där och kalla för vilket rekord av vårt liv vi vill studera. Människan kommer ej från apan (DFU 40 265: 282: 255). 
7 Translated from Swedish: Det talades mycket om en grotta 'underjordisk gång'. Den var i Kroksmåla. Öppningen var vid gränsen av Krokstorp och Lillaverke, vid södra ändan av Krokstorps sjön. Sagan säger att det var 7 bönder som knöt ihop 7 oxtömmar till ledningslina och gick in i grottan så långt som linan räckte. De tordes ej gå längre. De sade också att en hund hade gått in i grottan men kom aldrig ut igen. De hörde den skälla långt in i grottan. Det talades mycket om den grottan i Lillaverke när jag var där, men ingen vågade gå in där. Det är enda grottan jag hört om i den nejden. (DFU 40 265: 282: 254)

8 Translated from Swedish: Här är sagan om Stacka berg. Det var en Båtsman som hette Svala. Hans hem var i Svalehult, Madesjö socken. Han var ute på långresa i Kronans tjänst. Skeppet var i Stilla Havet när det en dag stannade och en Jätte tittade över relingen och frågade efter Båtsman Svala. Svala fördes fram till Jätten (Svala var förskräckt). Jätten sade till Svala "Var ej rädd. Intet ont ska hända dig. Du vet var Stacka berg är. Jag kunde ej stanna där och höra klockorna, så jag gick därifrån, men glömde min hund i berget. När du kommer hem, gå till berget och lös min hund. Han är bunden där inne i berget. Var ej rädd, ty så fort hunden bliver lös så springer han till mig. Då får du allt som är i berget. Där är 3 tunnor med guld och ett bord som har guldskiva och silverfot. Hunden är bunden med guldkedja." När Svala kom hem gick han till berget, fann nyckeln och gick in. Men när han såg hunden blev han så rädd, så han sprang ut och stängde dörren och kastade bort nyckeln. Kommen hem talade han om vad han sett och det spriddes ut att det fanns guld i Stacka berg. Folk kom dit och började gräva för att finna guldet men i stället för guld blev de sjuka. Så det blev förbjudet att gräva där. Efter en tid miste Svala förståndet. Stacka berg är i Svalehult, Madesjö socken (DFU 40 265: 282: 3).

9 Carl Nelson calls the devil Satan throughout.

\section{References}

Newspapers

Kvällsstunden: Hemmets och familjens veckotidning (1938-): https://kvallsstunden. se/, Västerås: Kvällsstunden.

Svenska Amerikanaren Tribunen (1936-1985): http://www.mnhs.org/newspapers/ swedishamerican/svenska-tribunen, Chicago, Illinois: Swedish American Newspaper Co.

Vimmerby tidning (1884-): http://www.vimmerbytidning.se/, Vimmerby: Vimmerby tidning.

\section{Archives}

The Institute for Language and Folklore, Department of Dialectology and Folklore Research, Uppsala (DFU, former ULMA) 


\section{Culture Unbound}

Journal of Current Cultural Research

Bd 11 420-22

DFU 40265

DFU 40 265: 282:
Recordings with Carl and Hilma Nelson made by Barbro Klein in Nelson's home in Manistique, Michigan, 12-15 April 1967. Karl Gösta Gilstring's collection of letters.

\section{1-285 Letters from Carl Nelson to Karl Gösta Gilstring} 1960- 1969.

DFU 40 265: 282: 3, 14 March 1960.

DFU 40 265: 282: 11, 11 June 1960.

DFU 40 265: 282: 254, 31 May 1967.

DFU 40 265: 282:2 55, 8 June 1967.

DFU 40 265: 282: 280, 30 June 1969.

DFU 40 265: 283 Correspondence between Barbro Klein and Karl Gösta Gilstring 1964-1974.

DFU 40 265: 284

Letters from Karl Gösta Gilstring to Carl Nelson, 19611969.

ULMA 34838 Karl Gösta Gilstring's folklore collection.

ULMA 34 838: 92 Memories from Oskar Parish.

ULMA 34 838: 92: 1 2,166 excerpts made from Carl Nelson's letters by Karl Gösta Gilstring.

ULMA 37313 Summaries of interviews about Karl Gösta Gilstring after his death, made by Eva-Lott Lindqvist 1993.

\section{Literature}

Ahmed, Sara (1999): "Home and Away: Narratives of Migration and Estrangement," International Journal of Cultural Studies, 2:3, 329-347.

Arvidsson, Alf (1999): Folklorens former, Lund: Studentlitteratur.

Atlas över svensk folkkultur (1957): Åke Campbell, Sigurd Erixon \& Åsa Nyman (eds): 1, Materiell och social kultur, 2, Sägen, tro och högtidssed, Uppsala: Kungliga Gustav Adolfs Akademien.

Bauman, Richard (1992): "Genre," Richard Bauman (ed.): Folklore, Cultural Performances, and Popular Entertainments: A Communications-centered Handbook, New York: Oxford University Press.

Cresswell, Tim (2015/2004): Place: An Introduction, Chichester: Wiley \& Sons Ltd.

Dundes, Alan (1986): "Den devolutionistiska premissen i folkloristisk teori," Stockholm: Institutet för folklivsforskning. Also in Journal of the Folklore Institute VI, 5-19.

Farahani, Fataneh (2007): Diasporic Narratives of Sexuality: Identity Formation among Iranian-Swedish Women, Stockholm University: Stockholm Studies in Ethnology 2.

Gustavsson, Karin (2014): Expeditioner $i$ det förflutna: Etnologiska fältarbeten och försvinnande allmogekultur under 1900-talets början, Stockholm: Nordiska museets förlag.

Gustavsson, Per \& Ulf Palmenfelt (2018): Folksagan $i$ Sverige: Berättelserna 3, Stockholm: Carlsson bokförlag, utgiven i samarbete med Vislanda hembygdsförening och Sagobygden.

Hall, Stuart (2002): "Kulturell identitet och diaspora," Catharina Eriksson, Maria Baaz \& Håkan Thörn (eds): Globaliseringens kulturer: Den postkoloniala paradoxen, rasismen och det mångkulturella samhället, Nora: Nya Doxa. 


\section{Culture Unbound}

Journal of Current Cultural Research

Heimo, Anne (2006): "Places Lost, Memories Regained: Narrating the 1918 Finnish Civil War in Sammatti," Annikki Kaivola-Bregenhoj, Barbro Klein and Ulf Palmenfelt (eds): Narrating, Doing, Experiencing: Nordic Folkloristic Perspectives, Helsinki: Finnish Literature Society, Studia Fennica Folkloristica 16, 47-63.

Johnstone Barbara (1990): Stories, Community and Place: Narratives from Middle-America, Bloomington: Indiana University Press.

Kaivola-Bregenhøj, Annikki (2006): "War as a Turning Point in Life," Annikki Kaivola-Bregenhoj, Barbro Klein \& Ulf Palmenfelt (eds): Narrating, Doing, Experiencing: Nordic Folkloristic Perspectives, Helsinki: Finnish Literature Society, Studia Fennica Folkloristica 16, 29-46.

Klein, Barbro (1980): Legends and Folk Beliefs in a Swedish American Community, Diss. Bloomington, 1970.

Klein, Barbro (1993): "Folkets röst: Svensk-amerikanska insändarbrev och folklorens betydelser," Nord Nytt, 52, 85-97.

af Klintberg, Bengt (1977): Svenska folksägner, Stockholm: Bokförlaget Pan / Nordstedts.

af Klintberg, Bengt (2010): The Types of the Swedish Folk Legend, Folklore Fellows' Communications 300, Helsinki: Academia Scientiarum Fennica

Lilja, Agneta (1991): "I den nationella odlingens tjänst: Dialekt- och folkminnesarkivet i pressen under sju årtionden," Kristina Hagren \& Agneta Lilja (eds): Sagt och gjort: Vänskrift till Wolter Ehn och Rune Västerlund, Uppsala: Dialekt- och folkminnesarkivet, $88-103$.

Lilja, Agneta (1999): "Den ideala uppteckningen i klassisk etnologi," Ulrika Wolf-Knuts (ed.): Vägen till arkivet, Åbo: NNF Publications, 21-48.

Lilja, Agneta (2012): "Ella Odstedt - liv och gärning," Ella Odstedt, Varulven i svensk folktradition, Stockholm: Malört förlag, 8-17.

Lindqvist, Eva-Lott (1993): "Väktare mot glömskans rike: En presentation av Karl Gösta Gilstrings folkminnesinsamling," Svenska landsmål och svenskt folkliv, 116, 63-78.

Löfgren, Orvar (1995): "Sakletarna: Om det materiellas betydelse i etnologin," Åke Daun (ed.): Ting, kultur och mening, Stockholm, Nordiska museets förlag, 137-160.

Lundell, Johan August (1939): "Herman Geijer och Landsmålsarkivet i Uppsala," Meddelanden från Landsmålsarkivet i Uppsala, 5-10.

Massey, Doreen (2007/1994): Space, Place and Gender, Cambridge: Polity Press.

Massey, Doreen (2010/2005): For Space, London: Sage.

Nybrokunskap (2018): http://www.nybrokunskap.se/ (accessed 17/9/18).

Nylund Skog, Susanne (2005): "Hisnande historier och talande tystnader: Berättelser i frågelistsvar," Charlotte Hagström \& Lena Marander-Eklund (eds): Frågelistan som källa och metod, Lund: Studentlitteratur, 149-168.

Nylund Skog, Susanne (2012): Livets vägar: Svenska judinnors berättelser om förskingring, förintelse, förtryck och frihet, Uppsala: Institutet för språk och folkminnen.

Nylund Skog, Susanne (2017): "Brev och belägg i jakten på folkminnen: Den vetenskaplige samlaren," Kulturella perspektiv, 26:1, 36-46.

Povrzanović Frykman, Maja (2001): "När våldet tar plats," Kjell Hansen \& Karin Salomonsson (eds): Fönster mot Europa: Platser och identiteter, Lund: Studentlitteratur, $125-165$.

Ryan, Marie-Laure (2004): Narrative across Media: The Languages of Storytelling, London: University of Nebraska Press.

Schechner, Richard (2013/2002): Performance Studies: An Introduction, London: Routledge.

Skott, Fredrik (2008): Folkets minnen: Traditionsinsamling i idé och praktik 1919-1964, Göteborg: Institutet för språk och folkminnen.

Taylor, Stephanie (2012/2010): Narrative of Identity and Place, London: Routledge.

Thompson, Stith (1957): Motif-Index of Folk-Literature, Volume Five, L-Z, Bloomington: Indian University Press.

Young, Katharine (1987): Taleworlds and Storyrealms: The Phenomenology of Narrative, Dordrecht: Martinus Nijhoff Publishers. 